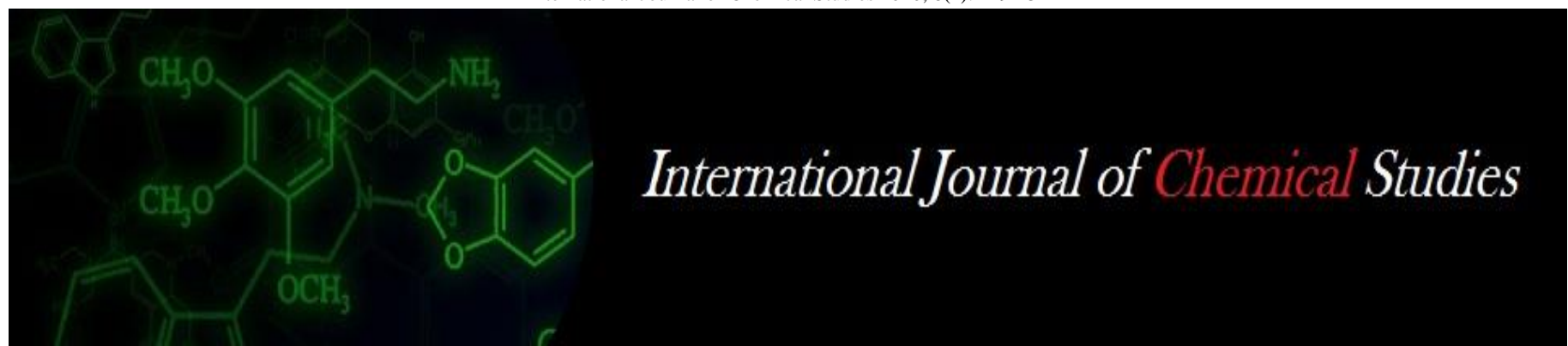

P-ISSN: 2349-8528

E-ISSN: 2321-4902

www.chemijournal.com

IJCS 2020; 8(2): 229-231

(C) 2020 IJCS

Received: 04-01-2020

Accepted: 06-02-2020

\section{PV Vekariya}

Main Oilseed Research Station,

Junagadh Agricultural

University, Junagadh, Gujarat,

India

\section{VP Andani}

Pulse Research Station,

Junagadh Agricultural

University, Junagadh, Gujarat,

India

\section{MK Chudasama}

Pulse Research Station, Junagadh Agricultural

University, Junagadh, Gujarat, India

\section{Corresponding Author:} PV Vekariya

Main Oilseed Research Station Junagadh Agricultural University, Junagadh, Gujarat, India

\section{Assessment of yield loss caused by powdery mildew disease in mungbean}

\author{
PV Vekariya, VP Andani and MK Chudasama
}

DOI: https://doi.org/ 10.22271/chemi.2020.v8.i2d.8773

\begin{abstract}
An experiment was conducted at the Instructional Farm of Agronomy, College of Agriculture, JAU, Junagadh during Kharif, 2015. The yield loss caused by powdery mildew disease was recorded on three treatments i.e. application of propiconazole @ $0.025 \%$, water sprays and untreated control under field conditions. Out of three treatments, lower disease intensity $(18.5 \%)$ and higher seed yield $(1242 \mathrm{~kg} / \mathrm{ha})$ was recorded in protected plots as compared to untreated control plots where disease intensity was $68.0 \%$ and seed yield was $709 \mathrm{~kg} / \mathrm{ha}$. With the application of propiconazole, $42.9 \%$ seed yield could be saved with the reduction of disease intensity by $72.8 \%$. Whereas, the application of water saved $5.7 \%$ seed yield with reduction of disease intensity by $13.8 \%$.
\end{abstract}

Keywords: Yield loss assessment, powdery mildew, plant disease intensity, Vigna radiata

\section{Introduction}

Green gram (Vigna radiata $\mathrm{L}$ ) is one of the most important and extensively cultivated pulse crops which is locally known as Mung and Golden bean. It is used as human food many other culinary products (Singh et al., 1988) ${ }^{[11]}$. It ranks second in nutritive value amongst pulses crop. The leguminous crops have the capacity to fix-atmospheric nitrogen through symbiotic nitrogen fixation. It is also used as green manure crop. It is grown in summer and Kharif season in northern India and in southern India. In India, it is the third important pulse crop In India, total area under Green gram cultivation is 40.70 lakh hectares, production 19.01 lakh tones and productivity of $406.98 \mathrm{~kg} / \mathrm{ha}$. The major Green gram growing states are Gujarat, Maharashtra, Rajasthan, Andhra Pradesh, Karnataka and Orissa. In Gujarat, area under cultivation is 1.53 lakh hectares production 0.88 lakh tones with the productivity of 526.09 $\mathrm{kg} / \mathrm{ha}$ (Anon., 2018) ${ }^{[1]}$. One of the major obstacles hampering green gram production is heavy incidence of the diseases. (Zote et al. 1985, Dhutraj and Zote, 2005) ${ }^{[12,3]}$.

The mung bean suffers from many diseases caused by fungi, bacteria, viruses, nematodes and abiotic stresses. Among these, powdery mildew disease caused by Erysiphe polygoni is a destructive disease which causes huge yield losses up to 50-90\% (Gupta and Mate, 2009) ${ }^{[5]}$. In Gujarat state, the disease appears during warm and humid weather conditions during flowering to maturity of crop. However, its severity may influenced by the different cultivars, planting time, cultural practices and prevailing environmental conditions (Singh et al.,1999) ${ }^{[10]}$.

\section{Materials and Method}

The experiment was conducted at the Instructional Farm of Agronomy, College of Agriculture, Junagadh Agricultural University, Junagadh during Kharif, 2015. For assessment of yield loss, green gram variety, GM- 4 was planted following sampling design in three strips $(15.00 \times 2.25$ $\mathrm{m})$ and $45 \times 10 \mathrm{~cm}$ spacing was maintained. One the appearance of disease, one strip was treated with foliar application of propiconazole @ $0.025 \%$ followed by two sprays at fifteen days interval. The remaining two strips were considered as check; untreated and water spray. The foliar application of propiconazole was carried out to maintain disease free condition. Eight samples of size $1.0 \times 1.0$ were drawn from each strip. The incidence of disease was recorded by following the $0-5$ scale on ten randomly selected plants from each sample and five leaves from each plant was selected after one week of last spray. 
The seed yield was recorded from each treatment from eight sub plots made in each treatment. Yield reduction (\%) was estimated on the basis of seed yield obtained (Gohil et al.1988) ${ }^{[4]}$.

$$
\text { Yield loss }(\%)=\frac{\text { Yield of treatment }- \text { Yield of check }}{\text { Yield of treatment }} \times 100
$$

\section{Results and Discussion}

To assessment of seed yield loss of green gram due to infection of powdery mildew, an experiment was conducted with three treatments including water spray and control during Kharif 2015. The foliar application of propiconazole $(0.025 \%)$ was given at 10 days interval starting from the initiation of disease to maintain disease free condition. The per cent disease intensity was recorded after seven days of last sprayed and seed yield was recorded from each treatment after harvesting.

Disease intensity and yield indicated that minimum disease intensity (18.53\%) was observed in foliar application of propiconazole 0.025 per cent. In water spray and without water spray (control) the per cent disease intensity was 58.67 per cent and 68.03 per cent, respectively. The maximum disease control (72.76\%) and maximum seed yield (1242 $\mathrm{kg} / \mathrm{ha}$ ) of green gram was obtained in foliar application of propiconazole $(0.025 \%)$. The treatment of water spray and without water (control) gave $752 \mathrm{~kg} / \mathrm{ha}$ and $709 \mathrm{~kg} / \mathrm{ha}$ seed yield, respectively. Similarly the minimum disease intensity and maximum seed yield were recorded with treatment of propiconazole $(0.025 \%)$ in other experiment conducted during Kharif 2015.

The results indicated that loss in seed yield was 42.91 per cent in greengram due to powdery mildew disease. If powdery mildew infected crop not protected timely caused considerable loss in yield of crop and timely application of propiconazole avoid loss in yield up to 42.91 per cent.

Foliar application of propiconazole 0.025 per cent gave 18.53 per cent disease intensity while 72.76 per cent disease inhibition control and $1242 \mathrm{~kg}$ per ha seed yield which was followed by water spray 58.67 per cent disease intensity 13.75 per cent disease control and $752 \mathrm{~kg}$ per ha seed yield and in control (without any spray) 68.03 per cent disease intensity 5.71 per cent disease control $5.71 \mathrm{~kg}$ per ha seed yield.

On the basis of that propiconazole $(0.025 \%)$ gave 42.91 per cent avoidable seed yield loss which was followed by water spray gave 5.71 per cent avoidable seed yield loss $752 \mathrm{~kg} / \mathrm{ha}$ and $709 \mathrm{~kg} / \mathrm{ha}$ seed yield, respectively. Similarly the minimum disease intensity and maximum seed yield were recorded with treatment of propiconazole $(0.025 \%)$ in other experiment conducted during Kharif 2015.

The results indicated that loss in seed yield was 42.91 per cent in greengram due to powdery mildew disease. If powdery mildew infected crop not protected timely caused considerable loss in yield of crop and timely application of propiconazole avoid loss in yield up to 42.91 per cent.

Similar results were obtained by Rathi et al. (2003) ${ }^{[7]}$, Munjal et al. (1963) [6], Raut and Wangikar (1979) ${ }^{[8]}$, Dakshayani and Mummigatti (2004) ${ }^{[2]}$ and Reddy et al. (2008) ${ }^{[9]}$.

Table 1: Assessment of yield loss in green gram due to powdery mildew

\begin{tabular}{|c|c|c|c|c|c|c|c|}
\hline $\begin{array}{c}\text { Sr. } \\
\text { No. }\end{array}$ & Treatment & $\begin{array}{c}\text { Per cent } \\
\text { Disease index } \\
\text { (PDI) }\end{array}$ & $\begin{array}{c}\text { Disease reduction } \\
\text { over check } \\
\text { (untreated) }\end{array}$ & $\begin{array}{c}\text { Disease reduction over } \\
\text { check (water spray) }\end{array}$ & $\begin{array}{c}\text { Seed yield } \\
\text { (kg/ha) }\end{array}$ & $\begin{array}{c}\text { Avoidable yield } \\
\text { loss (\%) over } \\
\text { check (untreated) }\end{array}$ & $\begin{array}{c}\text { Avoidable yield loss } \\
(\%) \text { over check } \\
\text { (water spray) }\end{array}$ \\
\hline 1 & Propiconazole @ 0.025\% & $18.53(25.43)$ & 72.76 & 68.42 & 1242 & 42.91 & 39.45 \\
\hline 2 & Check (water spray) & $58.67(50.00)$ & 13.75 & - & 752 & 5.71 & - \\
\hline 3 & Check (untreated) & $68.03(55.60)$ & - & -15.95 & 709 & - & - \\
\hline & SEm \pm & 0.80 & - & - & 51.76 & - \\
\hline & CD at 5\% & 2.40 & - & - & 203.22 & - & - \\
\hline & CV (\%) & 9.54 & - & - & 9.95 & - & - \\
\hline
\end{tabular}

* Mean of eight samples; figures in parenthesis are arc sin transformed values.

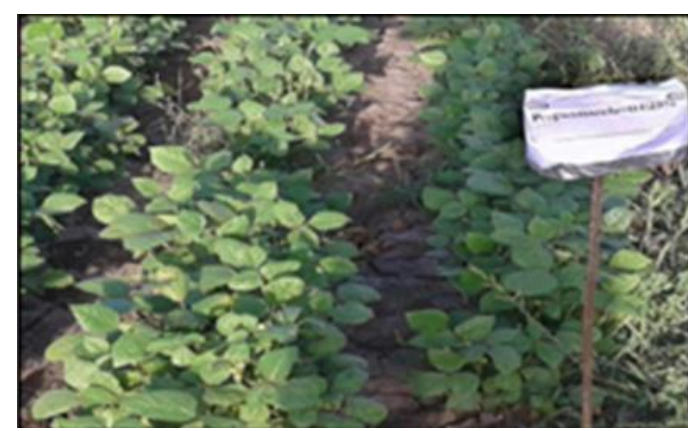

A

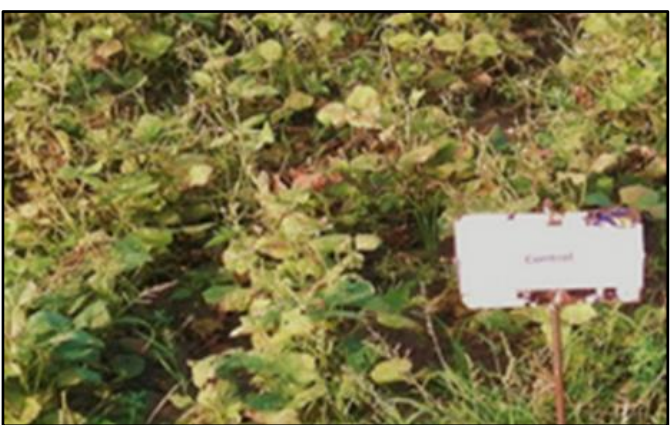

B

Fig 1: Field view of protected $[\mathrm{A}]$ and powdery mildew infected $[\mathrm{B}]$ green gram crop

\section{References}

1. Anonymous. Area, production and productivity of major pulses, 2018. http: // agropedia. iitk. ac. In $/ ? \mathrm{q}=$ content/area-production-and productivity -majorpulses. Accessed 24/9/2019.

2. Dakshayanani R, Mummigatti UV. Effect of powdery mildew on yield and yield components in greengram. Karnataka Journal of Agriculture Science. 2004; 17(3):448-450.
3. Dhutraj DN, Zote KK. Multiple disease resistant mungbean variety BPMR-145. Journal of Plant Diseases Science. 2005; 1:20-22.

4. Gohil VP, Jani SM, Dange SRS. Assessment of yield losses due to powdery mildew of cumin in North Gujarat. Indian Phytopathology. 1988; 41:156-157.

5. Gupta VR, Mate GD. Conidial size of Erysiphe polygoni influenced by the host reaction. Journal of Plant Diseases Science. 2009; 4(2):215-217. 
6. Munjal RL, Chenulu VV, Hora TS. Assessment of losses due to powdery mildew (Erysiphe polygoni DC) on pea. Indian Phytopathology. 1963; 16:268-270.

7. Rathi AS, Gupta PP, Jhorar BS. Yield losses due to powdery mildew disease in fenugreek (Trigonella foenum graecum L.). Journal of Spices and Aromatic Crops. 2003; 11(2):143-145.

8. Raut BT, Wangikar PD. Field evaluation of fungicides for the control of powdery mildew of pea. Pesticides. 1979; 13(12):21-23.

9. Reddy KS, Dhanasekar P, Dhole VJ. A review on powdery mildew disease resistance in mungbean. Journal of Food Legumes. 2008; 21(3):151-155.

10. Singh SW, Patil PB, Ingole OV. Powdery mildew of mungbean caused by Erysiphe polygoni. Journal of Plant Disease Science. 1999; 3(2):245.

11. Singh VP, Chhabra A, Kharb RPS. Production and utilization of mungbean in india. In proceedings of the second international symposium 16-20, November, 1987 Bangkok, Thailand, AVRDC, Shanhua, Tainan, 1988, 588.

12. Zote KK, Khalikar PV, Dandnaik BD. Efficacy of fungicides against powdery mildew of mungbean. Pesticide. 1985; 19(8):42-43. 